\title{
Rediscovering the Humane in the Human
}

\author{
Stacey Olster
}

The Gnostic Pynchon, by Dwight Eddins. Bloomington: Indiana UP, 1990.

173 pp. $\$ 25$.

After citing Derrida and Foucault on the ways what used to be called human has been redefined by the poststructuralist camp, and following their iconic statements with those of William Spanos, Paul Bové, and Thomas Docherty, to name a few, Dwight Eddins aligns his own name with those of Alan Wilde and John Fekete in the attempt to rediscover the humane in the human. Here the subject to be rescued by this revisionary Counterforce is Thomas Pynchon, and The Gnostic Pynchon mounts a campaign in which "the Pynchon whose world-view is suffused by acute nostalgia for vanished foundations and values" is united with "the Pynchon whose field of vision seems occupied with discontinuities and absurdities that threaten our sense of a comprehensible, mappable, even affirmable existence" (xi). At the same time, and with his own scholarly credentials as worthy weapons, Eddins also joins the Pynchon whose immersion in popular culture makes him at home at any beer blast to the Pynchon whose affinity for high modernist allusion would make him welcome at a Bloomsbury tea party. The result of both missions undertaken by this very accomplished, very well-researched, and-quite simply-very smart book is to situate this most contemporary of authors within a longrange literary tradition and to propose a "unified field theory" (xi) to account for an "encyclopedic" writer (to recall Edward Mendelson's early description) in a manner that is inclusive rather than exclusive.

In presenting his case as such a unified theory, Eddins recognizes the limits of any neat categorizations. Arguing that Pynchon's concerns are equally epistemological and ontological, and, as such, equally symptomatic of modernist and of postmodernist thought, Eddins advances a dialectic that provides an "interface" between the two literary movements. Thus, the indebtedness to Henry Adams in $V$. that suggests a longing for "phantom Standards" of the past, which Eddins deems a "reactionary" element in Pynchon's work, is perfectly compatible with the advocacy of "radical activism" in the later essay "Is It O.K. to Be a Luddite?" (xi, 6). 
Eddins finds the most "reactionary" of those longings in Pynchon's "Orphic naturalism" (5), the return to a primordial Earth, from the quests that inform the earliest stories (e.g. Dennis Flange's search for "Low-lands") through the ennobling of nature that pervades Gravity's Rainbow. (Vineland, which appeared the same year as Eddins's book, obviously continues this theme in its treatment of the Northwest woodlands.) According to Eddins, the return to such a sense of beneficent Earth forms Pynchon's counter to the impulses found within the power structures of cosmic conspiracy and the impotence promoted by cosmic indifference. The latter two prospects, in fact, constitute the main forms of gnosticism Eddins sees fluctuating in Pynchon's work: "cabalistic gnosticism," wherein the conspiracy professing absolute control of humans and absolute direction of history acquires the status formerly accorded deities; and "existential gnosticism," wherein terror generated by a cosmos of absolutely no control provokes an attraction to any kind of ordering and orderereven malevolent ones (12).

As the definitions of these two terms suggest, the gnostic Pynchon that Eddins explores (aided by the schemata of Hans Jonas and Eric Voegelin) is not a writer whose conception of religious structures is confined to those embodied by traditional or institutionalized sects. Eddins is aware, of course, of the lingering strengths of those traditions in Pynchon's fiction, as his discussion of the Virgin and the rose in $V$. indicates (56-61); and he understands quite well how the traditional impulse may extend beyond the bounds of religious practice, as his insight into $V$.'s fascist politics as growing out of her imperialistic brand of Catholicism proves (63). His main focus, however, is on those secular structures that assume (or presume to) the authority of religion in the void of religious collapse. Recognizing that "the loss of belief in a literal supernatural machinery in the universe, a loss consonant with modernity, need not mean the loss of religious awe and terror," Eddins also recognizes the transformation such conditions permit: "the secular becomes the religious if it presumes enough scope and power to challenge the preeminence of the latter" (94). And with no adjudicating deity to govern the acts of a presumptive power, "no 'Savior' to break into 'the closed system from without' as there is in Judaeo-Christian Gnosticism" (95), all acts become permissible by virtue of the actor's authorization alone.

"Gnostic slippage" is the term Eddins coins for this phenomenon (22). The occupational hazard of all the disinherited who populate Pynchon's world, it is the irony in which a need to redress grievances can result: Tristero challenges a Scurvhamite Puritan sect in The Crying of Lot 49, declines to secular status and challenges the Thurn and 
Taxis postal service, and, in protesting its oppressed status by obstructing mail routes and terrorizing mail carriers, is transformed into an oppressor in its own right. As embraced by those needing no redress because they have always been the dominators rather than the dominated, it becomes the principle that enables more of the same to continue: hence the ongoing operations of the Gravity's Rainbow Cartel.

With the perversion of values into their antitheses blurring the distinction between the heroic and the heinous, Pynchon's readers are left in realms of "ethical indeterminacy" (96) no less impenetrable than those "Regions of Indeterminacy" that engulf Slothrop at the end of Gravity's Rainbow. Indeed, the variety of ethically indeterminate questions Eddins raises about Pynchon's central concerns reminds us, after all these years and all our rereadings, how morally unsettling Pynchon's work truly is: "the central dichotomy of Pynchon's ethic" is "the opposition between those who serve entropy and those who oppose it" (42); "the mode of restoration is eerily inseparable from the mode of corruption" (38); the "constant question in Pynchon is how one combats enveloping evil without becoming a part of it" (48). That Eddins leaves most of these issues unresolved, acknowledging that "there is never a clear answer" (48), is no weakness of his book. Because most of the quandaries he cites stem from a confusion of sacred and profane, whereby " $[t]$ ranscending becomes a descending, a sliding downward from our higher potentialities; and transfiguring is a disfiguring of the world that had made the human possible" (81), Eddins opts for a condition of "metaxy" as the best those in Pynchon's world can reasonably expect: "an in-between in which humanity is to some degree illuminated by spiritual possibility without losing its base in the opaque materiality of natural process" (91). In the terms of this analysis, the "excluded middle" Oedipa Maas contemplates may not be such "bad shit" after all.

Because Eddins examines Pynchon's fiction developmentally, his shrewd and detailed readings of early works locating later themes that are merely hinted at, he withholds his final word on Pynchon's degree of resolution until his analysis of Gravity's Rainbow is completed. That final chapter elicits his most delicate balancing act yet, for the earlier discussion of the ways gnostic structures pervert transcendental ones in their efforts to subvert them is complicated here by a new discussion of the ways gnostic structures rely on language as a vehicle to achieve their ends. "Whether they belong to the seventeenth or the twentieth century, gnostic enterprises of cosmic domination are valorized by the Word" (132). "If the Christian claim 'In the beginning was the Word' is admitted, the Word is elevated from its status as shadowy image to 
ultimate reality and origin, while nature is demoted to a secondary emanation that is subject to the Word's changing will" (133)-in which case Pynchon, by relying on words to portray his own concerns, however salutary his intentions, falls prey to the same gnostic slippage as those preterite victims who become victimizers by the acts of restitution they initiate.

This, however, is one labyrinthine muddle for which Eddins supplies a roadmap out. By contrasting music with language, or, more to the point, music as a mode of cognition "'prior' to language" that "wed[s] human consciousness to primordial reality" from which the advent of language is construed as a fall (121), Eddins can absolve Pynchon of the onus of oppressor to the extent that the words of Gravity's Rainbow function as Orphic song rather than self-declared Sacred Text. This is clearly a climax towards which the novel itself moves, prefigured by Slothrop's "suckin' on his harp" and by the aqyn's chanting of the Kirghiz Light, anticipated by allusions to Rilke's Sonnets to Orpheus, and culminating with the song we are all invited to join in singing in the novel's last lines. And, fittingly, it is a climax that shows Eddins's powers of analysis at their best, for in pursuing this contrast between music and language in his last chapter, he encapsulates all the virtues that have been on display throughout the entire book: the foregrounding of Nietzsche recalling the range of philosophical learning that informs the work from start to finish (from Plato to Kant to Norman O. Brown); the comparisons to Joyce, Forster, and Wordsworth reminiscent of all those other literary references, most helpfully those modernist ones (to Conrad, Hemingway, Yeats, Lawrence, and Eliot, to name a few), that permeate and enrich so many of his discussions; the situating of his argument alongside those of other Pynchon scholars affirming the care with which he has framed his own critical contribution. In short, while Eddins may be able to grant Pynchon only the "possibility" of transcending a gnosis, as the final lines of this book assert, he has granted himself with The Gnostic Pynchon more than a probability of transcending the standards set by other critics - no small achievement, indeed. 